Bull. Fac. Agric., Cairo Univ., 60 (2009): 61-73.

\title{
PLANT WILDLIFE IN AL-AHRASH PROTECTORATE-RAFAH-NORTH SINAI-EGYPT
}

(Received: 31.8.2008)

\author{
By \\ K. F. El-Sahhar, W. M. Amer*, D. M. Nassar and L. A. Qasem \\ Department of Agricultural Botany, Faculty of Agriculture, \& *Department of Botany, \\ Faculty of Science, Cairo University, Giza, Egypt.
}

\begin{abstract}
This study aimed to analyze vegetation and soil of AL-Ahrash protectorate, Rafah, north Sinai, Egypt $\left(31^{\circ} 18^{\prime} \mathrm{N} 34^{\circ} 14^{\prime} \mathrm{E}\right)$; a developing resources natural reserve includes number of coastal sand dunes. The natural vegetation is mainly composed of Acacia saligna ( Labill.) Wendl. as a dominant and sand dune fixer species. The overall associated plant species traced in the area of the study were 25 belonged to 10 families. Poaceae were the only monocots traced family. Dicots, however, were represented by 9 families. The common annual non-woody species associated with Acacia saligna were Bromus scoparius, Hordeum murinum, Filago desertoum and Polycarpon succulentum; in addition to two perennial woody trees (Casuarina cunninghamiana and Tamarix aphylla). Soil analysis proved that Al-Ahrash soil is sandy, non saline, mostly lies in the alkaline side; heavy metal contents lie within the normal range of these metals in cultivated areas and an appreciable amount of organic matter is detected. According to the USDA taxonomy this soil belongs to order : Aridsols and suborder: Torripsamments. The plant life in AlAhrash protectorate faces difficulties due to irresponsible behaviour of some of the local people outside the protected area such as intensive grazing and excessive cutting. An urgent effort is needed to save the protectorate resources.
\end{abstract}

Key words: Acacia saligna, Al-Ahrash protectorate, resources exploitation, soil, vegetation.

\section{INTRODUCTION}

There are two primary causes of instability in ecosystems, changes in climate and changes in human activities. The greatly accelerated rate of change imposed by man, with which the response mechanisms of plants are unable to cope, resulting in the large-scale losses, not only of species but also of whole ecosystems. Human activities have the potential for imposing changes which are sudden and irreversible .Large-scale deforestation to provide land for agriculture and wood for fuel, intensive grazing by flocks of domesticated animals, which prevents the regeneration of forest and shrub communities through the destruction of their seedlings and industrial development and urbanization, have all had dramatic and directly destructive effects on natural ecosystems (Holden et al.,1993).

In 1983, the Egyptian Parliament enacted Law 102 that empowered the Prime Minister to issue decrees assigning prescribed territories as protected areas. This puts Egypt among the countries that are concerned with protection of nature and conservation of biodiversity (Anon., 1998).
Natural reserves, nowadays, cover a total area of about $150.000 \mathrm{~km}^{2}$ equal some $15 \%$ of the country with 27 protected areas proposed to reach 42 sites by year 2017 approaching $20 \%$ of the land area of Egypt. They represent ecologically diverse habitats and regions, including geological formations, cultural heritage sites, biodiversity hotspots and landscapes of outstanding natural beauty(Anon.,2008).

Mikhail (2002) stated that Egypt is rich in natural resources among which desert ecosystems need special care. Conservation of these resources is being challenged by rapid population growth and the massive size of the development needed to support it.

Azab and Noor (2003) and Othman et al. (2003)studied the area extends along north Sinai coastal plain which is considered an integral part of the Mediterranean sea. Coastal zones are important issues in the international debate on the environment and sustainable development. The coastal zone generally consists of the interface between land and sea in such an equation where the marine space and resources are as important as terrestrial ones. The coastal zone have become the 
major site for extensive economic activities where many of the coastal developing countries depend essentially on the scarce coastal resources for economic growth.

According to the Prime Ministerial Decrees 1429/1985 and 3379/1996, an area of $8 \mathrm{~km}^{2}, 370$ $\mathrm{km}$ eastern Cairo, in Rafah, North Sinai governorate, Al-Ahrash protectorate was declared as a developing resources protected area. This area is distinguished by sand dunes measuring some 60 $\mathrm{m}$ above sea leveL. It has a good vegetation cover, some of which has been planted by man in order to stabilize the dunes and curb sand movement in the region. The vegetation provides grazing and fire wood to local inhabitants and a shelter for animals and wild birds, but over use is threatening to degrade and destroy this resource. Location of such area within the framework of protection was performed in order to maintain an important form of the Mediterranean coastal environments (Anon., 2001).

Kutiel et al. (2004) stated that Acacia saligna (the dominant species in Al-Ahrash protectorate) was brought to Israel as early as the beginning of the $20^{\text {th }}$ century by the British rulers and the first Jewish settlers. It was brought for forestation and soil conservation of precipitous slopes, and for the stabilization of shifting sands as protection for development such as transportation arteries, agricultural lands, and residential areas.

The purpose of this investigation is to consider in detail various aspects of vegetation and soil of Al-Ahrash protectorate, Rafah, north Sinai, and to elucidate its possible interest expected in developing resources. The information gained from such study is welcomed to flourish the state-of-knowledge of this natural reserve, which is still rather meager.

\subsection{Study area}

\section{MATERIALS AND METHODS}

This investigation considers various aspects of the natural vegetation and soil of Al-Ahrash area, north Sinai $\left(31^{\circ} 18^{\prime} \mathrm{N} 34^{\circ} 14^{\prime}\right.$ E), $370 \mathrm{~km}$ eastern Cairo (Fig. 1) This area was declared as developing resources natural protectorate by the Prime Ministerial Decree number 1429/1985, modified by the Decree number 3379/1996. It covers an area of about $8 \mathrm{~km}^{2}$. The area under consideration was paid little research attention which might be due to its critical situation at the northern borders in the vicinity of the EgyptianPalestinian Authority borders.

Al-Ahrash area occupies part of the sand dune system between Al-Arish and Rafah cities, north
Sinai, close to the Mediterranean shore and falls under its climatic influence. The vegetation of this area is mainly supporting sand dunes fixation and stopping sand encroachment.

The climatic conditions over the area of the study are recorded by the meteorological data of Al-Arish Station of the Central Laboratory for Agricultural Climate, Ministry of Agriculture, Egypt (Table 1); being the nearest station to AlAhrash protectorate. The temperature average ranges from $13.6{ }^{\circ} \mathrm{C}$ in January to $27.0{ }^{\circ} \mathrm{C}$ in August. The area also receives $103.9 \mathrm{~mm}$. fall during 2007.

\subsection{Sampling procedure}

Two field expeditions were carried out to AlAhrash protectorate during March 2008 .This time was most fruitful concerning annual vegetation, related to the unusual rainy season.Field studies started with selection of ten permanent quadrates (Table 2). These quadrates are effectively representing the mean minimal area in the prevailing vegetation .Each quadrate measured 20 x $20=400 \mathrm{~m}^{2}$. Observations dealing with various aspects of the studied area were recorded on-site and prevailing conditions of the studied area were photographed.

In all studied quadrates the following vegetation parameters were recorded:

Vegetation composition, vegetation richness (as the average number of species in each quadrate and as the number of individuals per unit area) and plant cover calculated according to the following formula:

Plant cover $\%=\frac{\text { Total number of individual plants }}{\text { Total area }\left(400 \mathrm{~m}^{2}\right)} \times 100$

In addition, Acacia saligna richness (as the number of Acacia saligna trees per unit area) was investigated (Ali et al., 2000).

Vegetation monitoring of the area was carried out through collection and identification of the species in Cairo University Herbarium (CAI), based on the authentic herbarium samples and the basic related literature; including: Täckholm (1974), Danin (1983 and 1986), Gibali (1988), Boulos (1995 and 1999-2005), Abd El-Ghani and Amer (2003) and Othman et aL. (2003).Scientific names of plants were revised according to the checklists of Boulos (1995) and Bisby et al. (2008). The identified plant specimens were deposited in Rafah Herbarium ( a recently established Herbarium in Al-Ahrash protectorate for The National Project on Agro-technologies Based on Sinai Agriculture). 


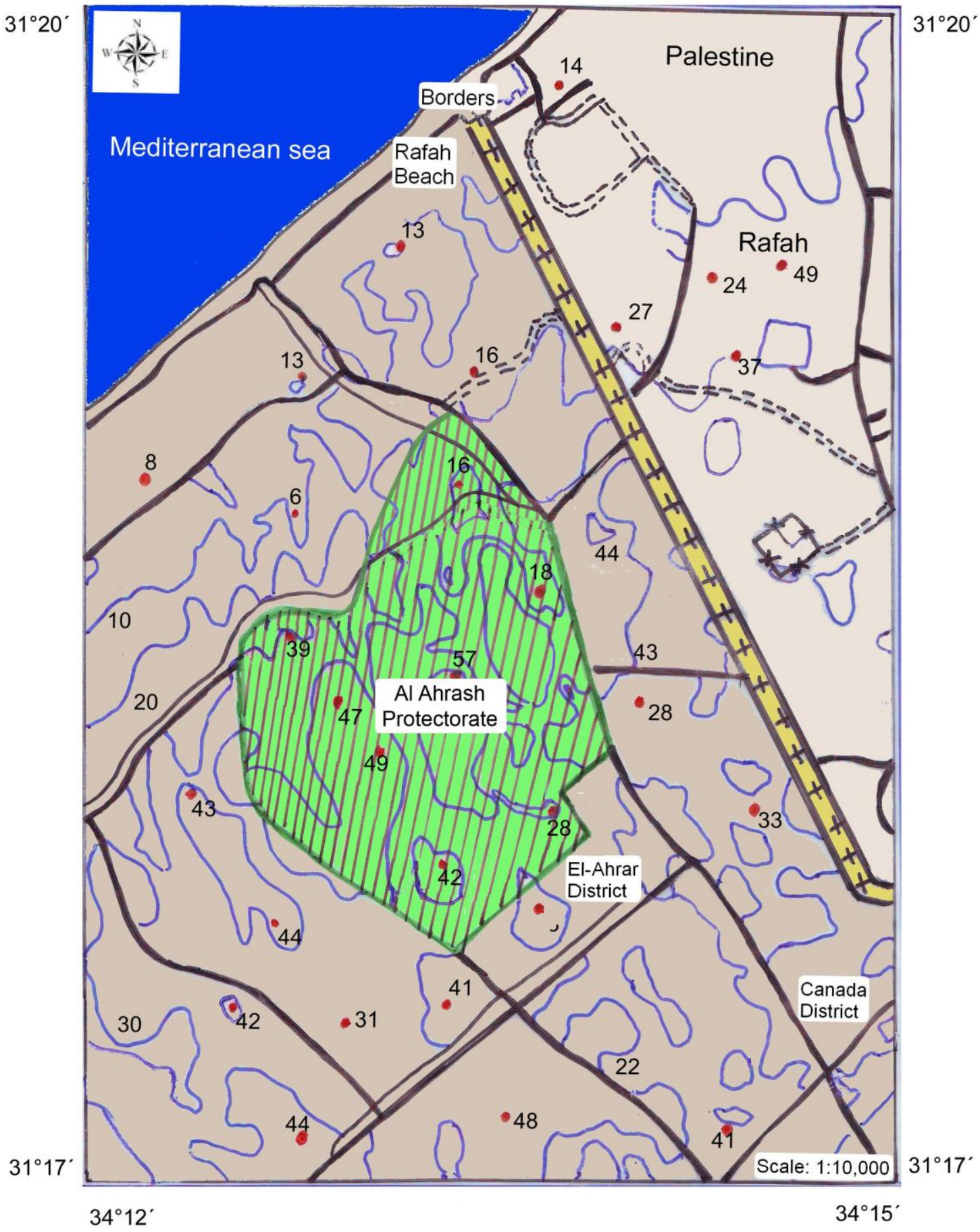

Fig. (1): A contour map showing location of Al-Ahrash protectorate, Rafah, North Sinai, Egypt. 
Table (1): Monthly trend of climatic details at Al-Arish region, north Sinai, Egypt.

\begin{tabular}{|c|c|c|c|c|c|c|c|}
\hline \multirow{2}{*}{ Month } & \multicolumn{3}{|c}{ Temperature ${ }^{\circ} \mathbf{C}$} & $\begin{array}{c}\text { RH } \\
\text { \% }\end{array}$ & $\begin{array}{c}\text { Wind speed } \\
\text { kont }\end{array}$ & $\begin{array}{c}\text { Avg. sun } \\
\text { shine, hrs }\end{array}$ & $\begin{array}{c}\text { Total } \\
\text { rain, mm }\end{array}$ \\
\cline { 2 - 7 } & Avg. & Max. & Min. & & & & \\
\hline 1 & 13.6 & 19.2 & 8.5 & 70 & 4.7 & 6.2 & 20.3 \\
\hline 2 & 13.9 & 19.9 & 9.1 & 69 & 5.5 & 6.0 & 17.1 \\
\hline 3 & 16.0 & 21.3 & 18.8 & 67 & 5.7 & 7.1 & 12.0 \\
\hline 4 & 18.7 & 23.7 & 13.3 & 67 & 4.8 & 7.9 & 6.1 \\
\hline 5 & 21.6 & 26.9 & 16.1 & 68 & 4.6 & 9.8 & 3.2 \\
\hline 6 & 24.7 & 28.9 & 18.9 & 72 & 4.5 & 11.9 & 0.0 \\
\hline 7 & 26.2 & 30.6 & 21.3 & 74 & 4.3 & 11.4 & 0.0 \\
\hline 8 & 27.0 & 31.1 & 21.9 & 75 & 4.0 & 10.5 & 0.2 \\
\hline 9 & 25.6 & 29.9 & 20.4 & 71 & 4.1 & 8.8 & 0.6 \\
\hline 10 & 23.2 & 28.5 & 18.0 & 73 & 3.5 & 7.7 & 6.0 \\
\hline 11 & 19.7 & 25.3 & 14.4 & 71 & 3.9 & 6.9 & 16.2 \\
\hline 12 & 15.5 & 21.4 & 10.2 & 66 & 4.6 & 4.6 & 22.2 \\
\hline
\end{tabular}

RH=Relative humidity. Longitude $33^{\circ} 75^{\prime} \mathrm{E}$, Latitude $31^{\circ} 27^{\prime} \mathrm{N}$, Altitude $15 \mathrm{~m}$.

Table (2): Location of studied quadrates in Al-Ahrash protectorate.

\begin{tabular}{|c|c|c|c|}
\hline $\begin{array}{c}\text { Quadrate } \\
\text { number }\end{array}$ & Latitude (N) & Longitude (E) & $\begin{array}{c}\text { Altitude } \\
(\mathrm{m})\end{array}$ \\
\hline 1 & $31^{\circ} 18^{\prime} 7.16^{\prime \prime}$ & $34^{\circ} 13^{\prime} 0.73^{\prime \prime}$ & 21.95 \\
\hline 2 & $31^{\circ} 18^{\prime} 6.84^{\prime \prime}$ & $34^{\circ} 13^{\prime} 0.06^{\prime \prime}$ & 22.25 \\
\hline 3 & $31^{\circ} 18^{\prime} 5.48^{\prime \prime}$ & $34^{\circ} 12^{\prime} 5.66^{\prime \prime}$ & 24.38 \\
\hline 4 & $31^{\circ} 18^{\prime} 3.49^{\prime \prime}$ & $34^{\circ} 13^{\prime} 0.00^{\prime \prime}$ & 33.53 \\
\hline 5 & $31^{\circ} 18^{\prime} 4.04^{\prime \prime}$ & $34^{\circ} 13^{\prime} 5.69^{\prime \prime}$ & 32.31 \\
\hline 6 & $31^{\circ} 18^{\prime} 4.81^{\prime \prime}$ & $34^{\circ} 13^{\prime} 1.23^{\prime \prime}$ & 30.78 \\
\hline 7 & $31^{\circ} 18^{\prime} 3.90^{\prime \prime}$ & $34^{\circ} 13^{\prime} 1.51^{\prime \prime}$ & 34.44 \\
\hline 8 & $31^{\circ} 18^{\prime} 2.81^{\prime \prime}$ & $34^{\circ} 13^{\prime} 2.23^{\prime \prime}$ & 42.37 \\
\hline 9 & $31^{\circ} 18^{\prime} 0.08^{\prime \prime}$ & $34^{\circ} 13^{\prime} 4.32^{\prime \prime}$ & 31.09 \\
\hline 10 & $31^{\circ} 18^{\prime} 1.66^{\prime \prime}$ & $34^{\circ} 13^{\prime} 1.51^{\prime \prime}$ & 34.44 \\
\hline
\end{tabular}

Latitude, Longitude and altitude data were obtained using GPS (12 CX.Garmin Olathe,KS,USA). 


\subsection{Soil analysis}

Samples of soils adjacent to roots of Acacia saligna in the ten studied quadrates at depth of 20$40 \mathrm{~cm}$ from the soil surface were collected and kept in refrigerator $\left(18{ }^{\circ} \mathrm{C}\right)$ for physical and chemical analysis carried out at Reclamation and Development Center for Desert Soils, Faculty of Agriculture, Cairo University. Giza, Egypt.

Dry sieve analysis of soil, bulk density, real density, field capacity, wilting point and total porosity were determined as described by Klute (1986).

Anion and cation contents in soil water extract (1:2.5) and $\mathrm{Ca} \mathrm{CO}_{3} \%$ of soil sample were tested according to the methods given by Richards (1954).

Percentage of organic matter as well as extractable contents of perchloric acid $\left(\mathrm{HClO}_{4}\right)$ and sulfuric acid $\left(\mathrm{H}_{2} \mathrm{SO}_{4}\right)$ digestable $\mathrm{N}, \mathrm{P}, \mathrm{K}$ and heavy metals ( $\mathrm{Fe}, \mathrm{Mn}, \mathrm{Zn}, \mathrm{Cu}, \mathrm{Cr}, \mathrm{Co}, \mathrm{Cd}, \mathrm{Pb}$ and $\mathrm{Ni}$ ) were determined in tested soils according to the methods of Anon (1970), Verlo (1981) and Page (1982).

\section{RESULTS AND DISCUSSION}

\subsection{Features of study area}

The investigated area is composed of number of coastal sand dunes ranged from 16 to 57 m.a.s.l. (Fig. 1).The natural vegetation is mainly composed of Acacia saligna (Fig. 2). This tree serves as a source of pastures, wood and animal shelter for the local inhabitants, beside its role as sand dune fixer species.

\subsection{Vegetation status}

Data in Tables $(3,4 \& 5)$ exhibit the plant species associated with Acacia saligna in the ten studied quadrates, number of individuals for various plant species and the plant cover at AlAhrash protectorate.

All studied quadrates revealed the dominance of Acacia saligna trees in the protectorate. The associated woody trees comprised of a few Tamarix aphylla (one tree as in Q2) and Casuarina cunninghamiana (12 trees as in Q3). Worthy to mention that the associated annuals were mainly dependent on the grazing status of the quadrate. Some quadrates as in case of Q5 (Fig. 3) possessed large number of annuals (12 species; 132 individuals). In contrast, other quadrates as Q1,6,8 and 10 were completely free from any associated plant species with Acacia saligna. The overall species traced in area of the study were 25 belonged to 10 families. Family Poaceae was the only traced family from
Monocotyledoneae, while Dicotyledoneae were represented by 9 families.

Quadrate 1 was a pure stand of Acacia saligna (21 trees), with $5.3 \%$ plant cover. No associated species was observed which might be due to over grazing impact which appeared also in case of young branches of Acacia saligna. Trees reached up to $130 \mathrm{~cm}$ in height.

Quadrate 2 comprised 5 Acacia saligna trees reached up to $190 \mathrm{~cm}$ in height, plus 8 associated plant species (84 individuals).The co-dominant species to Acacia saligna were Polycarpon succulentum, Stipa capensis and Urtica urens. A single tree of Tamarix aphylla was also observed. The plant cover was $22.3 \%$.

Quadrate 3 was composed of 5 Acacia saligna trees in addition to 7 associated species of 83 individuals. The co-dominant species were Filago desertorum and Hordeum murinum. The woody tree Casuarina cunninghamiana particularly developed in this stand with a considerable number (12 trees). This might be attributed to the local bedouin plantation for fire wood and shade. The plant cover in this quadrate was $22.0 \%$. Acacia saligna trees reached up to $230 \mathrm{~cm}$ in height .

Quadrate 4 included one Acacia saligna tree reached $215 \mathrm{~cm}$ in height. Iflago spicata and Hordeum murinum were the co-dominant among the recorded 8 species (66 individuals) associated with Acacia saligna. The plant cover was 16.8 $\%$.

Quadrate 5 (Fig. 3) was composed of 9 Acacia saligna trees .The highest tree reached $135 \mathrm{~cm}$. Associated plant species were 12 with a considerable number of individuals, being 132 . Bromus scoparius, Cutandia memphitica and Hordeum murinum were on top of the codominant species. This quadrate was the most conserved one among the studied quadrates. The plant cover reached $35.3 \%$.

Quadrate 6 was a pure Acacia saligna stand (13 trees ). The plant cover was $3.3 \%$. Acacia saligna reached $325 \mathrm{~cm}$ in height.

Quadrate 7 included 7 Acacia saligna trees associated with 4 species; Iflago spicata and Urtica urens were co-dominant species. The plant cover was $7.5 \%$. Acacia saligna reached $350 \mathrm{~cm}$ in height.

Quadrate 8 was a pure stand of Acacia saligna; 6 trees. The plant cover was $1.5 \%$. Trees reached $190 \mathrm{~cm}$ in height.

Quadrate 9 was composed of a single tree of Acacia saligna, in addition to 6 associated species 


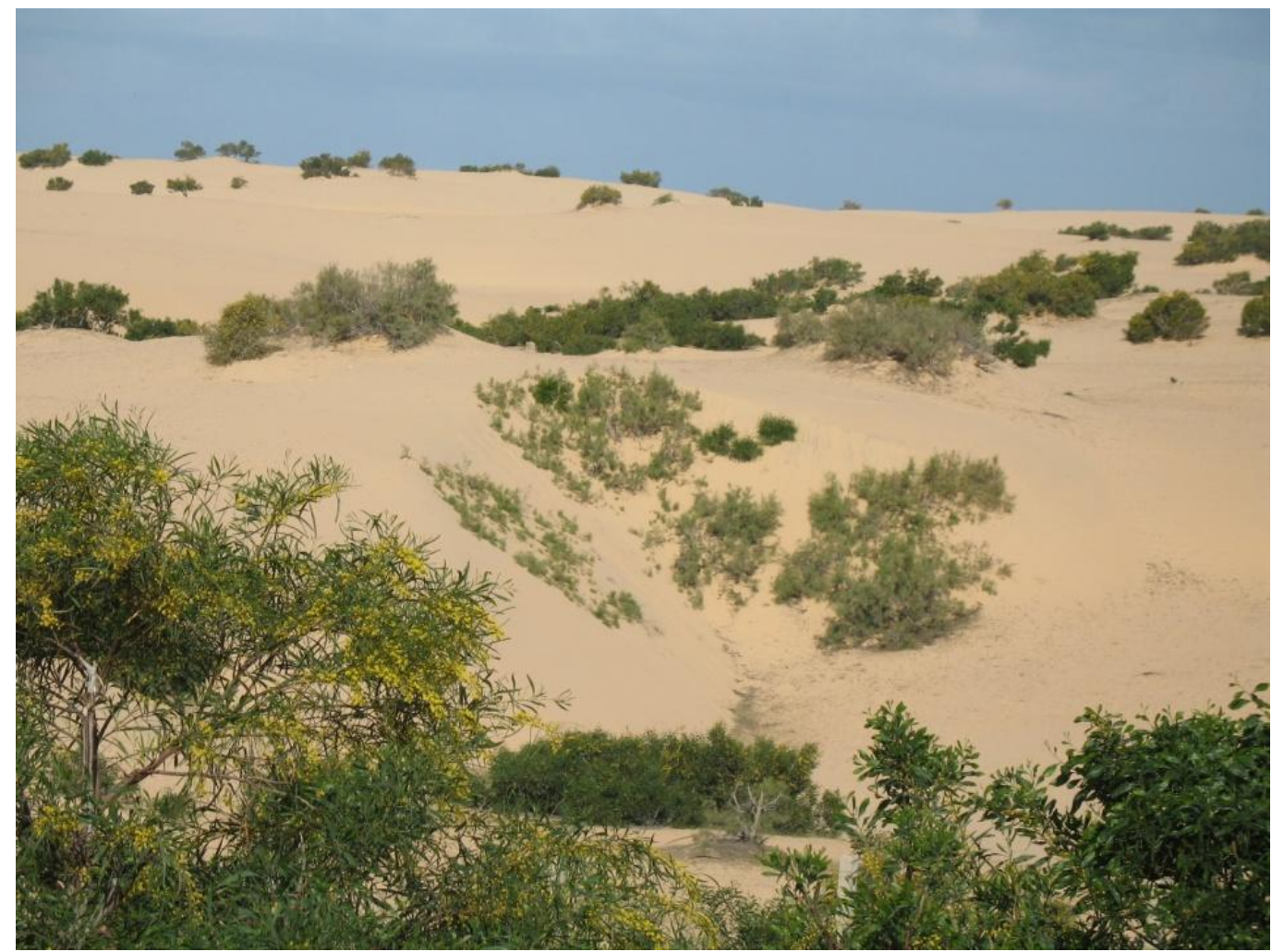

Fig. (2): The coastal sand dunes of Al-Ahrash protectorate mainly covered by Acacia saligna.

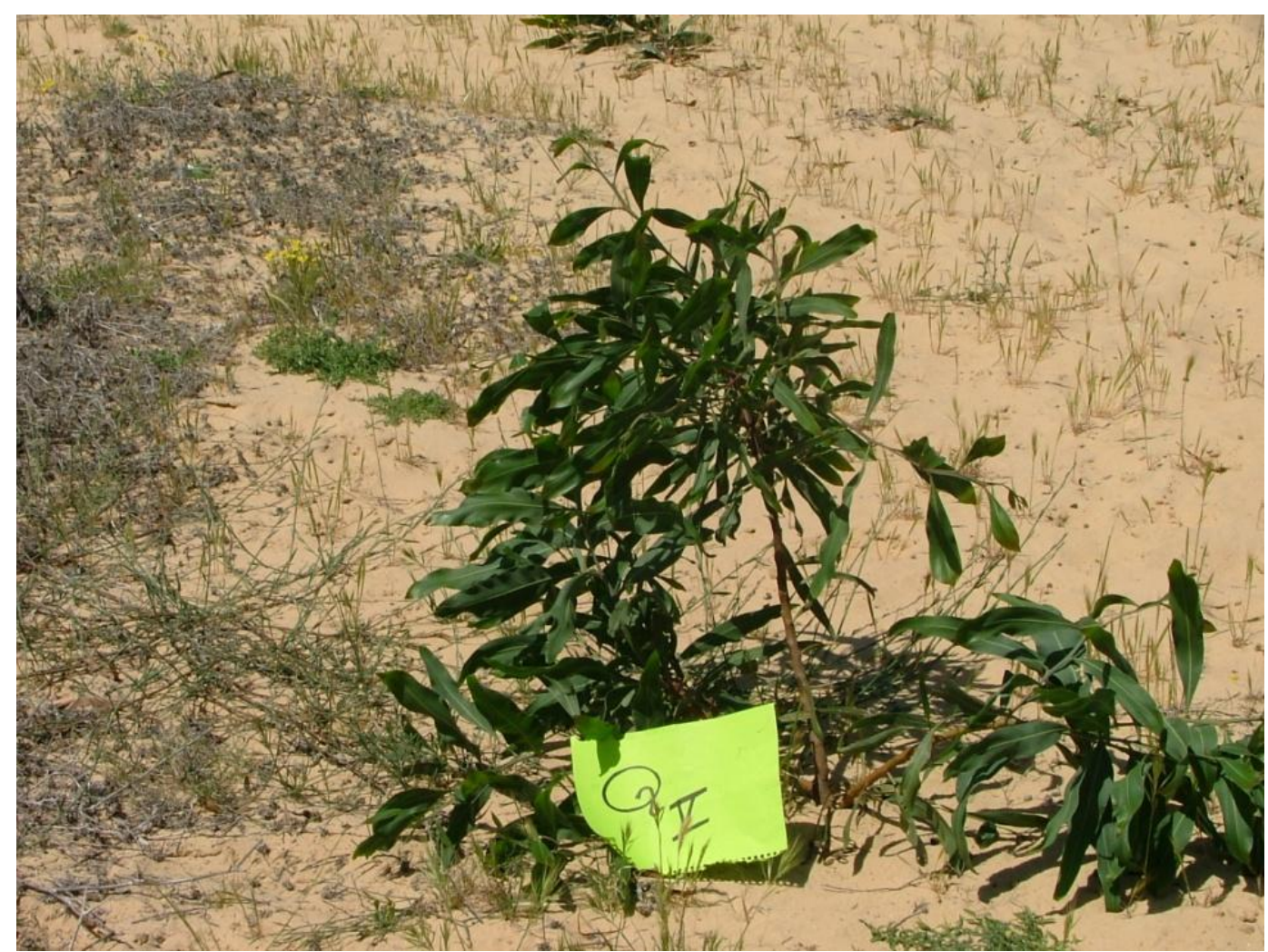

Fig. (3): Quadrate 5 at Al-Ahrash protectorate with rich associated annuals as no grazing activity is detected, being the most conserved stand. 
Table (3): Plant species associated with Acacia saligna in the studied quadrates at Al Ahrash protectorate. Species are arranged alphabetically in each quadrate.

\begin{tabular}{|c|c|c|c|}
\hline $\begin{array}{c}\text { * Quadrate } \\
\text { No. }\end{array}$ & Associated plant species & $\begin{array}{c}\text { No. of } \\
\text { individuals }\end{array}$ & Family \\
\hline \multirow[t]{8}{*}{2} & $\begin{array}{l}\text { Cutandia memphitica (Spreng.) } \\
\text { Benth. }\end{array}$ & 2 & Poaceae \\
\hline & $\begin{array}{l}\text { Polycarpon succulentum (Delile) } \\
\text { J.Gay }\end{array}$ & 33 & Caryophyllaceae \\
\hline & Rumex pictus Forssk. & 2 & Polygonaceae \\
\hline & Salsola kali L. & 1 & Chenopodiaceae \\
\hline & Senecio glaucus L. & 2 & Asteraceae \\
\hline & Stipa capensis Thunb. & 23 & Poaceae \\
\hline & Tamarix aphylla (L.) Karst. & 1 & Tamaricaceae \\
\hline & Urtica urens L. & 20 & Urticaceae \\
\hline \multirow[t]{7}{*}{3} & Casuarina cunninghamiana Miq. & 12 & Casuarinaceae \\
\hline & Filago desertorum Pomel & 35 & Asteraceae \\
\hline & Hordeum murinum L. & 23 & Poaceae \\
\hline & Phalaris paradoxa $\mathrm{L}$. & 2 & Poaceae \\
\hline & Rumex pictus Forssk. & 3 & Polygonaceae \\
\hline & Senecio glaucus L. & 6 & Asteraceae \\
\hline & Urtica urens L. & 2 & Urticaceae \\
\hline \multirow[t]{8}{*}{4} & Bromus madritensis L. & 3 & Poaceae \\
\hline & Bromus scoparius L. & 9 & Poaceae \\
\hline & $\begin{array}{l}\text { Cutandia memphitica (Spreng.) } \\
\text { Benth }\end{array}$ & 8 & Poaceae \\
\hline & $\begin{array}{l}\text { Erodium glaucophyllum (L.) L' } \\
\text { Hér. }\end{array}$ & 4 & Poaceae \\
\hline & Hordeum murinum L. & 16 & Poaceae \\
\hline & Ifloga spicata (Forssk.) Sch. Bip. & 20 & Asteraceae \\
\hline & Senecio glaucus L. & 2 & Asteraceae \\
\hline & Silene succulenta Forssk. & 4 & Caryophyllaceae \\
\hline \multirow[t]{12}{*}{5} & Bromus scoparius L. & 50 & Poaceae \\
\hline & Centaurea alexandrina Delile. & 5 & Asteraceae \\
\hline & Chenopodium album $\mathrm{L}$. & 2 & Chenopodiaceae \\
\hline & $\begin{array}{l}\text { Cutandia memphitica (Spreng.) } \\
\text { Benth. }\end{array}$ & 17 & Poaceae \\
\hline & $\begin{array}{l}\text { Eremobium aegyptiacum (Spreng.) } \\
\text { Asch. }\end{array}$ & 6 & Brassicaceae \\
\hline & Erodium crassifolium L' Hér. & 3 & Poaceae \\
\hline & Hordeum murinum L. & 15 & Poaceae \\
\hline & Marrubium vulgare L. & 7 & Lamiaceae \\
\hline & Polygonum equisetiforme $\mathrm{Sm}$. & 10 & Polygonaceae \\
\hline & Senecio glaucus L. & 4 & Asteraceae \\
\hline & Sisymbrium irio L. & 7 & Brassicaceae \\
\hline & $\begin{array}{l}\text { Verbesina encelioides (Cav.) Benth. \& } \\
\text { Hook. F. ex A.Gray }\end{array}$ & 6 & Asteraceae \\
\hline
\end{tabular}

(Cont.) 
Table (3): Cont.

\begin{tabular}{|c|c|c|c|}
\hline $\begin{array}{c}\text { * Quadrate } \\
\text { No. }\end{array}$ & Associated plant species & $\begin{array}{c}\text { No. of } \\
\text { individuals }\end{array}$ & Family \\
\hline \multirow[t]{4}{*}{7} & Bromus scoparius L. & 3 & Poaceae \\
\hline & Ifloga spicata (Forssk.) Sch. Bip. & 8 & Asteraceae \\
\hline & Senecio glaucus L. & 5 & Asteraceae \\
\hline & Urtica urens $\mathrm{L}$. & 7 & Urticaceae \\
\hline \multirow[t]{6}{*}{9} & Bromus scoparius L. & 4 & Poaceae \\
\hline & Cutandia memphitica (Spreng.) Benth. & 2 & Poaceae \\
\hline & Erodium crassifolium L’ Hér. & 1 & Poaceae \\
\hline & Ifloga spicata (Forssk.) Sch. Bip. & 5 & Asteraceae \\
\hline & Polycarpon succulentum (Delile) J. Gay. & 2 & Caryophyllaceae \\
\hline & Senecio glaucus L. & 3 & Asteraceae \\
\hline
\end{tabular}

*Quadrates 1,6,8 and 10 were pure Acacia saligna stands, completely free from associated plant species.

Table (4): Number of individuals for each of the plant species associated with Acacia saligna in the area studied at $\mathbf{A l}-\mathbf{A h r a s h}$ protectorate. Species are arranged alphabetically.

\begin{tabular}{|c|c|c|}
\hline Family & Associated species & $\begin{array}{c}\text { No. of individuals } \\
\text { of each species }\end{array}$ \\
\hline Poaceae & Bromus madritensis L. & 3 \\
\hline Poaceae & Bromus scoparius L. & 66 \\
\hline Casuarinaceae & Casuarina cunninghamiana Miq. & 12 \\
\hline Asteraceae & Centaurea alexandrina Delile & 5 \\
\hline Chenopodiaceae & Chenopodium album L. & 2 \\
\hline Poaceae & Cutandia memphitica (Spreng.) Benth. & 29 \\
\hline Brassicaceae & Eremobium aegyptiacum (Spreng.) Asch. & 6 \\
\hline Poaceae & Erodium crassifolium L' Hér. & 4 \\
\hline Poaceae & Erodium glaucophyllum (L.) L' Hér. & 4 \\
\hline Asteraceae & Filago desertorum PomeL. & 35 \\
\hline Poaceae & Hordeum murinum L. & 54 \\
\hline Asteraceae & Ifloga spicata (Forssk.) Sch.Bip. & 33 \\
\hline Lamiaceae & Marrubium vulgare L. & 7 \\
\hline Poaceae & Phalaris paradoxa $\mathrm{L}$. & 2 \\
\hline Caryophyllaceae & Polycarpon succulentum (Delile) J. Gay & 35 \\
\hline Polygonaceae & Polygonum equisetiforme $\mathrm{Sm}$. & 10 \\
\hline Polygonaceae & Rumex pictus Forssk. & 5 \\
\hline Chenopodiaceae & Salsola kali L. & 1 \\
\hline Asteraceae & Senecio glaucus L. & 22 \\
\hline Caryophyllaceae & Silene succulenta Forssk & 4 \\
\hline Brassicaceae & Sisymbrium irio L. & 7 \\
\hline Poaceae & Stipa capensis Thunb. & 23 \\
\hline Tamaricaceae & Tamarix aphylla (L.) Karst. & 1 \\
\hline Urticaceae & Urtica urens L. & 29 \\
\hline Asteraceae & $\begin{array}{l}\text { Verbesina encelioides (Cav.) Benth. \& } \\
\text { Hook. f. ex A.Gray. }\end{array}$ & 6 \\
\hline
\end{tabular}


Table (5): Status of Acacia saligna, number of individuals of different plant species and plant cover percentage in the studied quadrates at $\mathrm{Al}$-Ahrash protectorate.

\begin{tabular}{|c|c|c|c|c|c|c|c|c|}
\hline \multirow{3}{*}{$\begin{array}{c}\text { Quadrate } \\
\text { No. }\end{array}$} & \multicolumn{5}{|c|}{ Acacia saligna } & \multirow{3}{*}{$\begin{array}{c}\text { No. of } \\
\text { individuals } \\
\text { of associated } \\
\text { species }\end{array}$} & \multirow{3}{*}{$\begin{array}{c}\text { Sum of } \\
\text { individual } \\
\text { plants }\end{array}$} & \multirow{3}{*}{$\begin{array}{c}\text { Cover } \\
\%\end{array}$} \\
\hline & \multirow{2}{*}{$\begin{array}{c}\text { No. of } \\
\text { trees }\end{array}$} & \multirow{2}{*}{ Status } & \multicolumn{3}{|c|}{ * Av. height, cm } & & & \\
\hline & & & $\mathbf{L}$ & $\mathbf{M}$ & $\mathbf{S}$ & & & \\
\hline 1 & 21 & OG & 130 & 120 & 85 & 0.0 & 21 & 5.3 \\
\hline 2 & 5 & $\mathbf{G}$ & 190 & 80 & 70 & 84 & 89 & 22.3 \\
\hline 3 & 5 & $\mathbf{G}$ & 230 & 140 & 80 & 83 & 88 & 22.0 \\
\hline 4 & 1 & C & 215 & - & - & 66 & 67 & 16.8 \\
\hline 5 & 9 & $\mathbf{C}$ & 135 & 85 & 35 & 132 & 141 & 35.3 \\
\hline 6 & 13 & OG & 325 & 115 & 80 & 0.0 & 13 & 3.3 \\
\hline 7 & 7 & G & 350 & 180 & 75 & 23 & 30 & 7.5 \\
\hline 8 & 6 & OG & 190 & 120 & 80 & 0.0 & 6 & 1.5 \\
\hline 9 & 1 & OG & 250 & - & - & 17 & 18 & 4.5 \\
\hline 10 & 9 & OG & 300 & 160 & 90 & 0.0 & 9 & 2.3 \\
\hline
\end{tabular}

th a few number of individuals. The plant cover was $4.5 \%$.

Quadrate 10 was a pure Acacia saligna stand (9 trees ). The plant cover was $2.3 \%$. The height of trees reached $300 \mathrm{~cm}$.

The impact of grazing was noticed in most of the studied area. This appeared as grazed young branches of Acacia saligna and absence of associated plant species in some stands. Moreover, few number of palatable species were grown in few numbers of individuals.

\subsection{Soil analysis}

A comprehensive analysis of various physical and chemical characteristics of the soil of the study area was carried out to enrich knowledge about the soil as a major element of the ecosystem in the investigated area.

Soil attributes for Al-Ahrash protectorate are summarised in Table (6). It is evident that the sandy nature of investigated quadrate soils affected all the values of the reported soil characteristics. For instance, the bulk density lay in a range of 1.41 up to $1.77 \mathrm{~g} / \mathrm{cm}^{3}$ with an average of $1.49 \mathrm{~g} / \mathrm{cm}^{3}$. However, the real density average was $2.70 \mathrm{~g} / \mathrm{cm}^{3}$ with a range from 2.63 to $2.80 \mathrm{~g} / \mathrm{cm}^{3}$. Moreover, the total porosity value was $38.2 \%$ on the average and ranged between 35.0 and $42.7 \%$.

Concerning water constants of soil, it is a naive that sandy soils retain less water due to their low content of silt and clay fractions and organic matter. In this respect, the field capacity averaged $7.38 \%$ with a range from 6.40 to $10.35 \%$. The wilting point values averaged $2.77 \%$ and ranged from 2.31 to $4.61 \%$ resulting in a low content of available water reaching $2.77 \%$ on the average. The low soil content of available water is considered an obstacle in developing such areas.

Munzbergova and Ward (2002) in their study on Acacia trees mentioned their effects on the environment beneath their canopies including enhancement of soil fertility (increased nitrogen, organic carbon, phosphorus and microbial biomass) according to their capability of nitrogen fixation. In the mean time, trees may also have a negative effects on under-storey vegetation via below-ground competition, which could reduce the amounts of nutrients and water available.

The soil analysis indicated that soil of $\mathrm{Al}$ Ahrash protectorate is non saline (Ec: $0.27 \mathrm{dS} / \mathrm{m}$ ) mostly lies in the alkaline side ( $\mathrm{pH} 7.21)$. Roux and Middlemiss (1963) stated that Acacia saligna does better on neutral to alkaline soil.

Results obtained reveal that $\mathrm{P}(36 \mathrm{ppm})$ and $\mathrm{K}$ (120 ppm) values using acidic extraction were relatively high in spite of soil sandy texture, absence of fertilizer application and the depletion of such resources by growing associated annual species.

The relatively high amount of nitrogen content (41.2 ppm) might be a result of nitrogen fixation by Acacia saligna trees. The growing plants also led to existence of appreciable amount of the organic matter $(1.09 \%)$, in addition to the root fragments mixed with the soil samples collected for analysis. 
Table (6): Average values and ranges of soil analysis in the ten studied quadrates of $\mathrm{Al}$-Ahrash protectorate.

a. Dry sieve analysis

\begin{tabular}{|c|c|c|c|c|c|c|c|}
\hline \multirow[b]{2}{*}{ Value $\%$} & \multicolumn{6}{|c|}{ Diameter (mm) } & \multirow[b]{2}{*}{$\begin{array}{c}\text { Texture } \\
\text { class }\end{array}$} \\
\hline & $\begin{array}{c}\text { Very } \\
\text { coarse } \\
\text { sand 1-2 }\end{array}$ & $\begin{array}{c}\text { Coarse sand } \\
0.5-1\end{array}$ & $\begin{array}{c}\text { Medium } \\
\text { sand } \\
0.25-0.5\end{array}$ & $\begin{array}{c}\text { Fine sand } \\
0.1-0.25\end{array}$ & $\begin{array}{c}\text { Very fine } \\
\text { sand } \\
0.05-0.1\end{array}$ & $\begin{array}{c}\text { Silt }+ \\
\text { clay } \\
<0.05\end{array}$ & \\
\hline Average & 0.00 & 1.90 & 66.17 & 28.25 & 1.66 & 0.49 & \multirow[b]{2}{*}{ Sand } \\
\hline Range & 0.00 & $\begin{array}{c}0.43- \\
4.09\end{array}$ & $\begin{array}{c}55.57- \\
76.60\end{array}$ & $\begin{array}{l}12.30- \\
41.55\end{array}$ & $\begin{array}{c}0.33- \\
2.80\end{array}$ & $\begin{array}{c}0.19- \\
0.88\end{array}$ & \\
\hline
\end{tabular}

b. Water constants

\begin{tabular}{|c|c|c|c|c|c|}
\hline Value & $\begin{array}{c}\text { Bulk density } \\
\left(\mathrm{g} / \mathrm{cm}^{3}\right)\end{array}$ & $\begin{array}{c}\text { Real density } \\
\left(\mathrm{g} / \mathrm{cm}^{3}\right)\end{array}$ & $\begin{array}{c}\text { Field capacity } \\
(\%)\end{array}$ & $\begin{array}{c}\text { Wilting point } \\
(\%)\end{array}$ & $\begin{array}{c}\text { Total porosity } \\
(\%)\end{array}$ \\
\hline Average & 1.49 & 2.70 & 7.38 & 2.77 & 38.2 \\
\hline Range & $1.41-1.77$ & $2.63-2.80$ & $6.40-10.35$ & $2.31-4.61$ & $35.0-42.7$ \\
\hline
\end{tabular}

c. Anion, cation and $\mathrm{CaCO}_{3}$ contents

\begin{tabular}{|l|c|c|c|c|c|c|c|c|c|c|}
\hline Value & \multirow{2}{*}{ Ec dS/m } & $\mathrm{pH}$ & $\mathrm{Ca} \mathrm{CO}_{3}$ & \multicolumn{3}{|c|}{ Soluble anions (meq/l) } & \multicolumn{4}{|c|}{ Soluble cations (meq/l) } \\
\cline { 5 - 11 } & & & & $\mathrm{HCO}_{3}^{-}$ & $\mathrm{Cl}^{-}$ & $\mathrm{SO}_{4}^{-}$ & $\mathrm{Na}^{+}$ & $\mathrm{K}^{+}$ & $\mathrm{Ca}^{++}$ & $\mathrm{Mg}^{+}$ \\
\hline Average & 0.27 & 7.21 & 2.07 & 1.6 & 0.5 & 0.6 & 0.3 & 0.1 & 1.1 & 1.2 \\
& & & & & & & & & & \\
\hline Range & $0.22-$ & $7.11-$ & $1.43-$ & $1.2-$ & $0.5-$ & $0.1-$ & $0.3-$ & $0.1-$ & $0.8-$ & $1.0-$ \\
& 0.35 & 7.31 & 2.86 & 2.2 & 0.8 & 1.3 & 0.5 & 0.2 & 1.5 & 1.3 \\
\hline
\end{tabular}

d. Organic matter and extractable contents $\mathbf{N}, \mathbf{P}$ and $\mathrm{K}$

\begin{tabular}{|l|c|c|c|c|}
\hline Value & $\mathrm{N}(\mathrm{ppm})$ & $\mathrm{P}(\mathrm{ppm})$ & $\mathrm{K}(\mathrm{ppm})$ & Organic matter $\%$ \\
\hline Average & 41.2 & 36 & 120 & 1.09 \\
\hline Range & $33.6-50.4$ & $29-40$ & $90-150$ & $0.90-1.30$ \\
\hline
\end{tabular}

e. Extractable content of heavy metals

\begin{tabular}{|c|c|c|c|c|c|c|c|c|c|}
\hline $\begin{array}{c}\text { Value } \\
(\mathrm{ppm})\end{array}$ & $\mathrm{Fe}$ & $\mathrm{Mn}$ & $\mathrm{Zn}$ & $\mathrm{Cu}$ & $\mathrm{Cr}$ & $\mathrm{Co}$ & $\mathrm{Cd}$ & $\mathrm{Pb}$ & $\mathrm{Ni}$ \\
\hline Average & 783 & 16.4 & 12.2 & 7.4 & 0.2 & 2.4 & nd & nd & 1.0 \\
& & & & & & & & & \\
\hline Range & $312-$ & $9.6-$ & $0.1-$ & $0.6-$ & $0.0-$ & $0.9-$ & nd & nd & $0.0-$ \\
& 1200 & 27.7 & 30.9 & 11.4 & 1.8 & 3.9 & & & 3.3 \\
\hline
\end{tabular}

$\mathrm{Nd}=$ Not detected. 


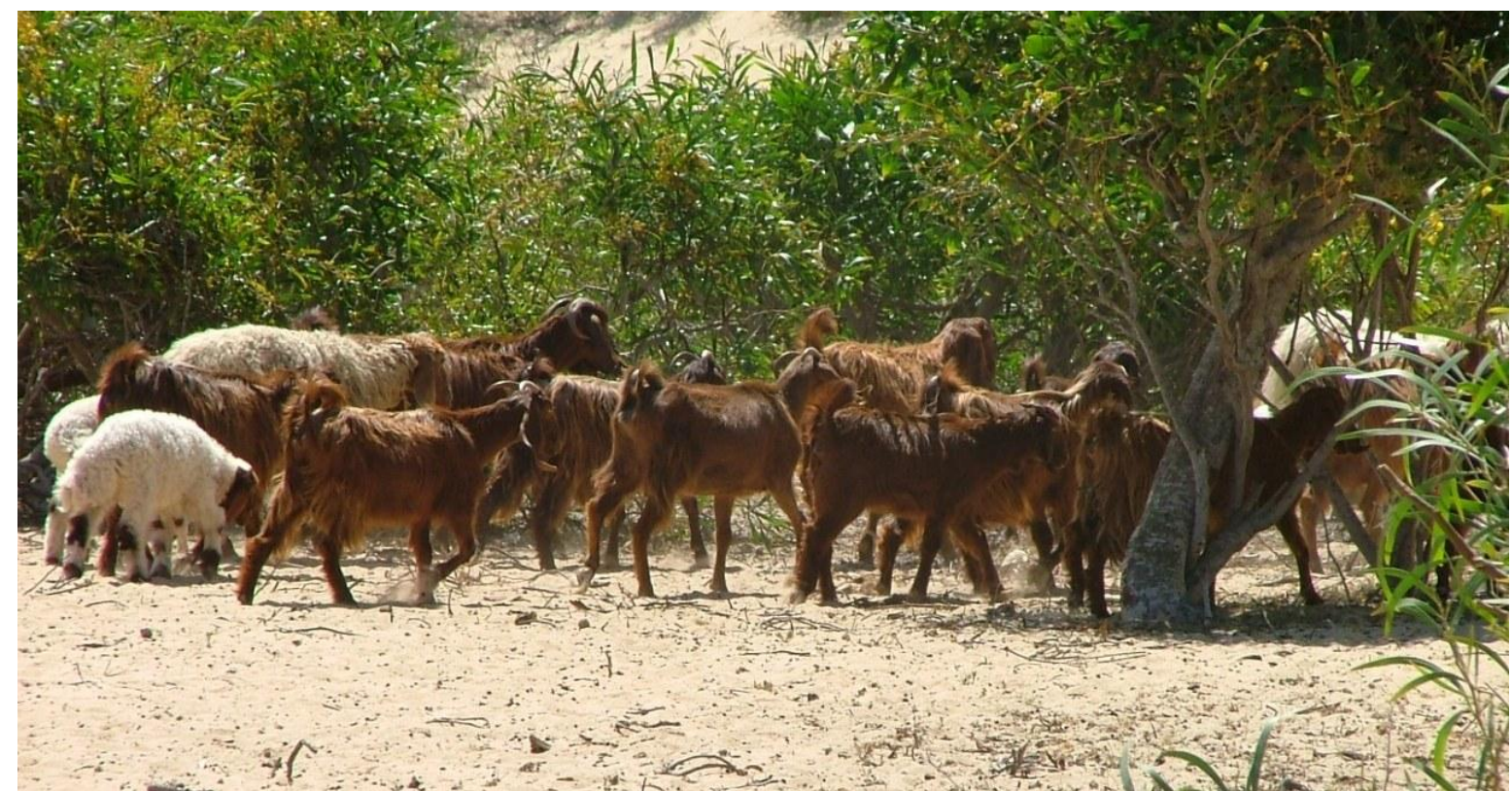

Fig. (4): Sheep and goats are grazing on the land of Al-Ahrash protectorate.

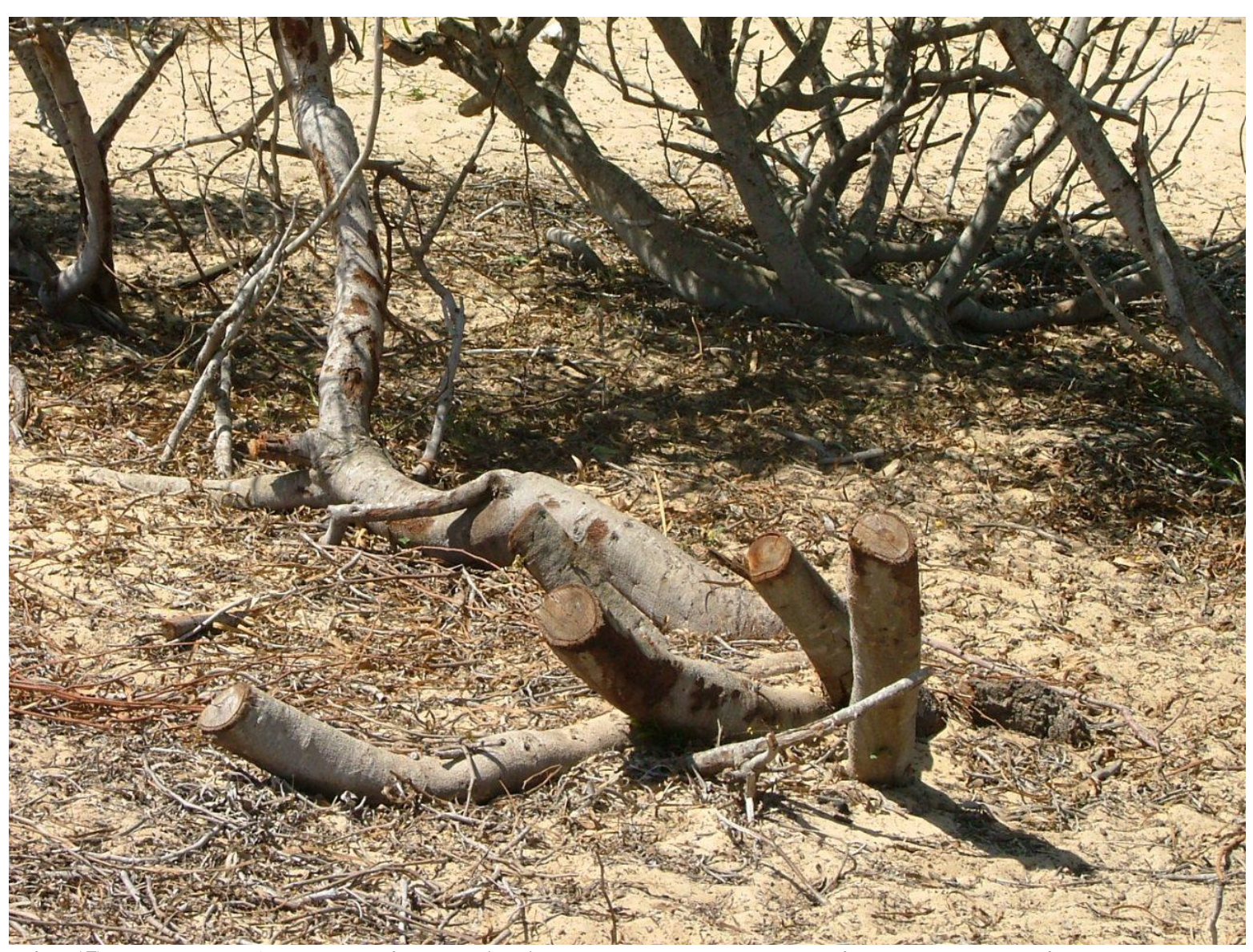

Fig. (5): Acacia saligna growing at Al-Ahrash protectorate subjected to excessive cutting for the benefit of local people. 
The total amounts of heavy metals in tested soil samples lay within the normal range of these metals in cultivated areas.

To conclude, the previously given data on physical and chemical characteristics of $\mathrm{Al}$ Ahrash protectorate soil, and following the USDA taxonomy of soil (Anon., 2005) based on horizon characterization, morphological characters and soil climate, proved that this soil belongs to: Order: Aridsols and Suborder: Torripsamments

\subsection{Problems facing resources exploitation of Al-Ahrash protectorate}

According to the Prime Ministerial Decrees 1429/1985 and 3379/1996, Al-Ahrash area has been declared a developing resources protected area. The natural vegetation of this area makes it a good resource of pastures, timber and a shelter for wild animals and birds. This is in addition to the vital role of Acacia saligna, the main plant species in this area, preventing sand movements in such location. In the mean time, Al-Ahrash protectorate is considered an important form of the Mediterranean coastal environments.

Unexpected environmental hazards have been observed which threaten conservation and sustainable use of the natural resources in this area. The protectorate faces difficulties due to irresponsible behaviour of some of the inhabitant people outside the protected area. Noteworthy to mention that Law 102/1986 for nature protectorates includes strict regulations to manage natural reserves of Egypt. Article (2) forbidden action commitments lead to destruction or deterioration of the natural environment or harm the biota. Article (4) included that the administrative body of each protectorate is empowered to guide and educate the public about the natural resources within protectorates.

However, the following irresponsible behaviour of some of the local inhabitants was observed. In Fig. (4) bedouin is grazing sheep and goats through Al-Ahrash protectorate causing damage to the natural vegetation and transmission of plant diseases from cultivated fields outside the protected area to plants inside the protectorate . Moreover, young local inhabitants drive their motorcycles through the protected area of AlAhrash causing damage to different environmental elements. It is worthy to mention that Acacia saligna growing in this area (Fig. 5) is subjected to loss due to excessive cutting by bedouin for fuel and charcoal production. An urgent effort is needed to save the protectorate resources.

\section{Acknowledgement}

The authors appreciate the unlimited support and facilities offered by Prof. Dr. Nabil A. Hegazi, The National Project on Agro-Technologies Based on Biological Nitrogen Fixation for Development of Sinai Agriculture, Rafah, Egypt, (Faculty of Agriculture, Cairo University).

\section{REFERENCES}

Abd El-Ghani M.M. and Amer W.M. (2003). Soilvegetation relationships in a coastal desert plain of southem Sinai. Journal of Arid Environments 55: 607-628.

Ali M.M., Dickinson G. and Murphy K. (2000). Predictors of plant diversity in a hyper arid desert wadi ecosystem. Journal of Arid Environments 45: 215-230.

Anon. (1970). FAO (Food and Agriculture Organization of the United Nations) Physical and chemical methods of soil and water analysis. Soil Bulletin No.10.

Anon. (1998). Egypt : National strategy and action plan for biodiversity conservation, Ministry of State for the Environment, Egyptian Environmental Affairs Agency, Department of Nature Conservation. National Biodiversity Unit. 85pp.

Anon. (2001). Egypt's protected areas. Ministry of State for Environmental Affairs. National Parks of Egypt.

Anon. (2005). Soil Survey Staff. Soil Taxonomy. A basic system of soil classification for making and interpreting surveys. $2^{\text {nd }}$. Edit. Agriculture handbook No.436, USDA, Nat. Res. Cons. Service.

Anon. (2008). Issues of Ministry of State for Environmental Affairs, Egyptian Environmental Affairs Agency.

Azab M.A. and Noor A.M. (2003). Change detection of the north Sinai coast by using remote sensing and geographic information system. Conference of Environment (2003). (30/9-2/10/2003). Ministry of State for the Environment, Egyptian Environmental Affairs Agency.10pp.

Boulos L. (1995). Flora of Egypt. Checklist. AlHadara Publishing, Cairo, Egypt. 283pp.

Boulos L.(1999-2005). Flora of Egypt , 4 Vols. Al Hadara Publishing, Cairo, Egypt.

Bisby F.A., Roskov Y.R., Orrell T.M., Nicolson D., Paglinawan L.E., Bailly N., Kirk P. M., Bourgoin T. and van Hertum, J. eds (2008). Species 2000 \& ITIS Catalogue of life: 
2008 Annual Checklist. CD-ROM, Species 2000: Reading. U.K.

Danin A. (1983). Desert Vegetation of Israel and Sinai. Jerusalem: Cana Publishing House: $148 \mathrm{pp}$.

Danin A. (1986). Flora and vegetation of Sinai. Proceeding of the Royal Society of Edinburgh ,89 B: 159-168.

Gibali M.A. (1988). Studies on the flora of Northern Sinai M. Sc. Thesis , Fac. Agric., Cairo Univ., Egypt. 403 pp.

Holden J., Peacock J. and Williams T.(1993). Genes, Crops and the Environment. Cambridge University Press. p 1-10.

Klute A. (1986). Method of Soil Analysis. (Ed.), Part 1. Physical and Mineralogical Methods. Agronomy Monogr. No. 9, $2^{\text {nd }}$. Edit. ASA and SSSA, Madison, WI., USA.

Kutiel P.B., Cohen O. and Shoshany M. (2004). Invasion rate of the alien species Acacia saligna within coastal sand dune habitats in Israel. Israel Journal of Plant Science 52: 115124.

Mikhail G. (2002). Egypt's Biodiversity and the Quest for Conservation. Ministry of State for Environmental Affairs. Egyptian Environmental Affairs Agency. $40 \mathrm{pp}$.

Munzbergova Z. and Ward D. (2002). Acacia trees as keystone species in Negev desert ecosystems. Journal of Vegetation Science 13: 227-236.

Othman A. A., Amer W.A., Fayez M., Monib M. and Hegazi N.A. (2003). Biodiversity of diazotrophs associated to the plant cover north Sinai deserts. Archives of Agronomy and Soil Science 49: 683-705.

Page A.L. (1983). Methods of Soil Analysis. (Ed.) Part 2. Chemical and Microbiological Analysis. Agronomy Monogr., N0 9. $2^{\text {nd }}$. Edit. ASA and SSSA, Madision, Wl. USA.

Richards L.A. (1954). Diagnosis and Improvement of Saline and Alkali Soils. (Ed.) USSL Staff. Agric. Handbook No 60.

Roux E.R. and Middlemiss E. (1963). Studies in the autecology of the Australian acacias in South Africa. I .The occurrence and distribution of Acacia cyanophylla and A. cyclops in the Cape Province. South African Journal of Science 59: 286-294.

Täckholm V. (1974). Students' flora of Egypt $\left(2^{\text {nd }}\right.$ Edit.). Cairo University Press. 888 pp.

Verlo M. (1981). Analytical Problems and Methods in Trace Element Studies. Chapter 4, in Cottenie, A (ed) Trace Elements in Agriculture and the Environment. Laboratory of Analytical and Agrochemistry, State Univ., Ghent, Belgium.

$$
\begin{aligned}
& \text { الحياة النباتية البرية في محمية الأحر اش برفح ـ شمال سينـاء ـ مصر } \\
& \text { قاسم فؤاد السحار ـ * وفاء محروس عامر ـ داليا محمد عبد العزيز نصار ـ لما أسعد قاسم } \\
& \text { قسم النبات الزر اعي ـ كلية الزر اعة ـ * قسم النبات ـ كلية العلوم }
\end{aligned}
$$

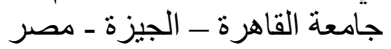

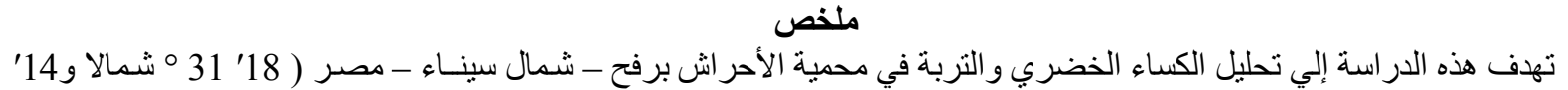

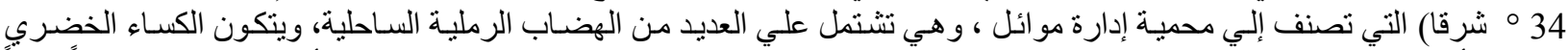

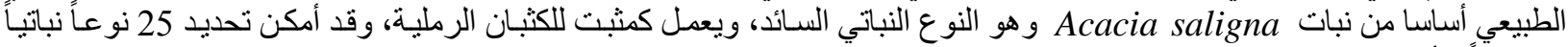

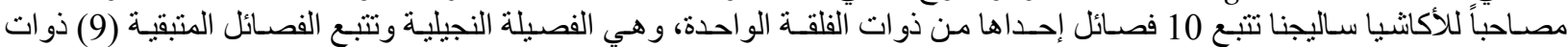

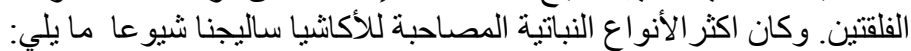

\section{Bromus scoparius - Hordeum murinum - Filago desertorum - Polycarpon succulentum} فضلا عن القليل من أثجار الكازواريناو الإتل.

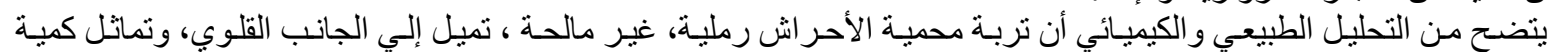

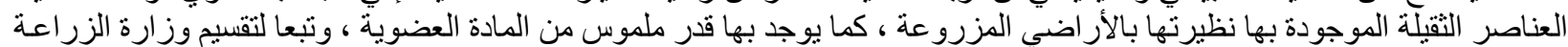

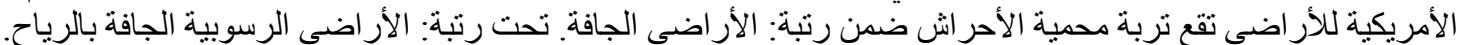

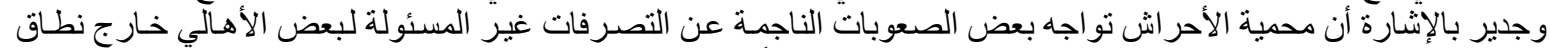

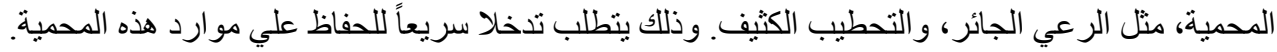

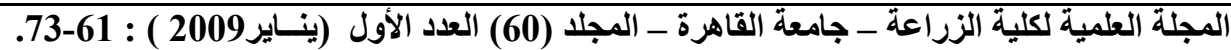

